\title{
Gingival Polyp
}

National Cancer Institute

\section{Source}

National Cancer Institute. Gingival Polyp. NCI Thesaurus. Code C3948.

A non-neoplastic nodular lesion that arises from the gingiva. 